\title{
Engajamento médico no processo de fluxo do paciente promove aumento da taxa de alta antes das 11:00
}

Dr Marcius Conceição Prestes, coordenador do programa de fluxo do paciente

Enf Vanessa Ferraboli dos Santos, Enf Renata Pinzon Fraga, Enf Higia Pires Pizzato, time de fluxo do paciente

Dr Fernando Starosta de Waldemar, diretor de especialidades médica

\section{São Paulo, 20 à 21 de Março de 2019}

Introdução: O programa de fluxo de um Hospital Privado de Porto Alegre, criado em 2016, visa garantir segurança ao paciente por meio do cuidado certo, no lugar certo, na hora certa, durante todo o tempo. A saída hospitalar tardia de pacientes com alta médica, comporta-se como gargalo, limitando a movimentação eficientes de enfermos na instituição. O represamento do fluxo em leitos observacionais do pronto socorro gera superlotação do mesmo e significativos risco assistenciais.

Objetivo: Aumentar o indicador de taxa de altas médicas realizadas antes 11:00, de 48\% em 2017 para meta de $85 \%$ ao final de 2018 .

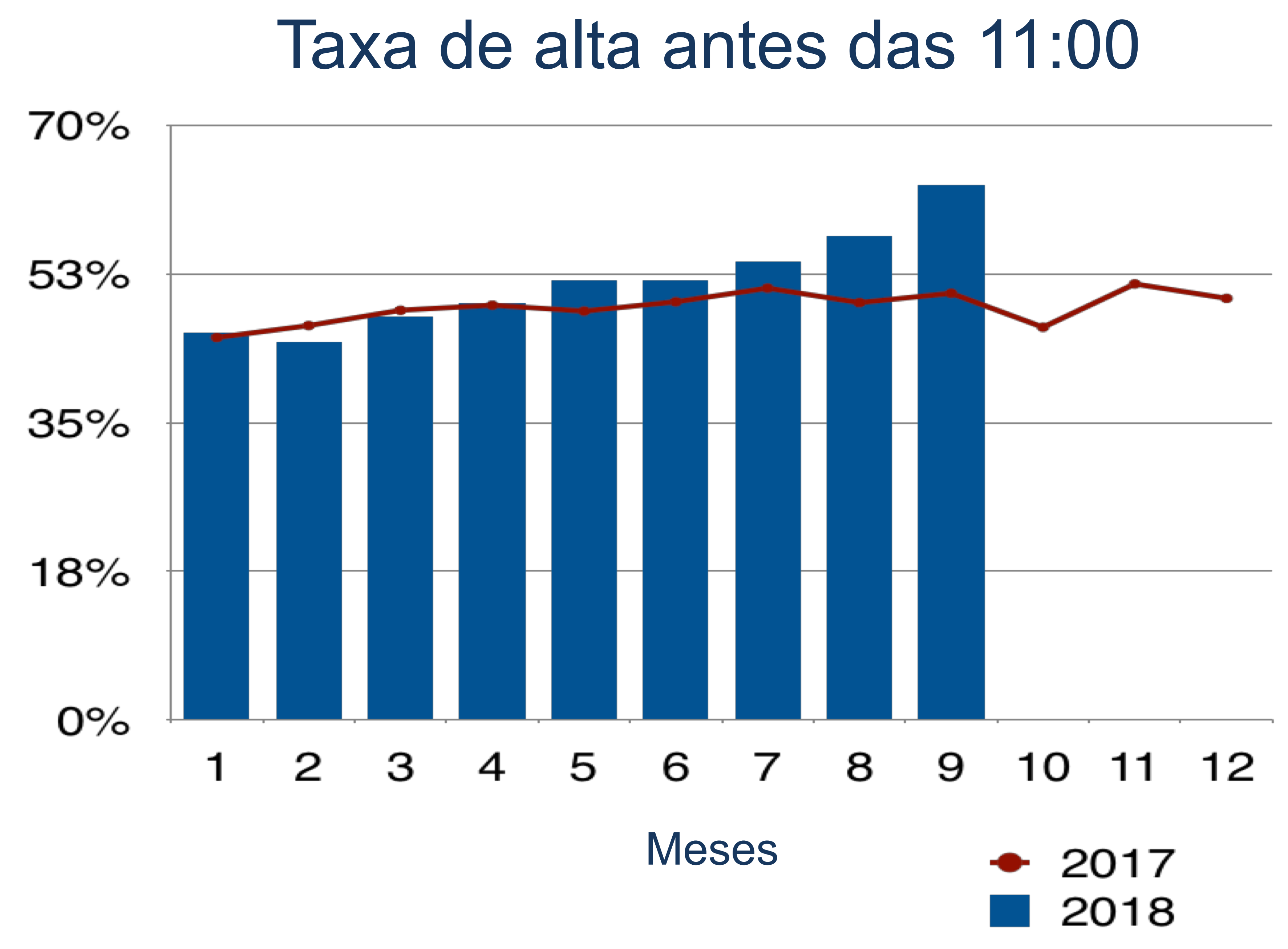

\section{Taxa de alta antes das 11:00 em 2017}

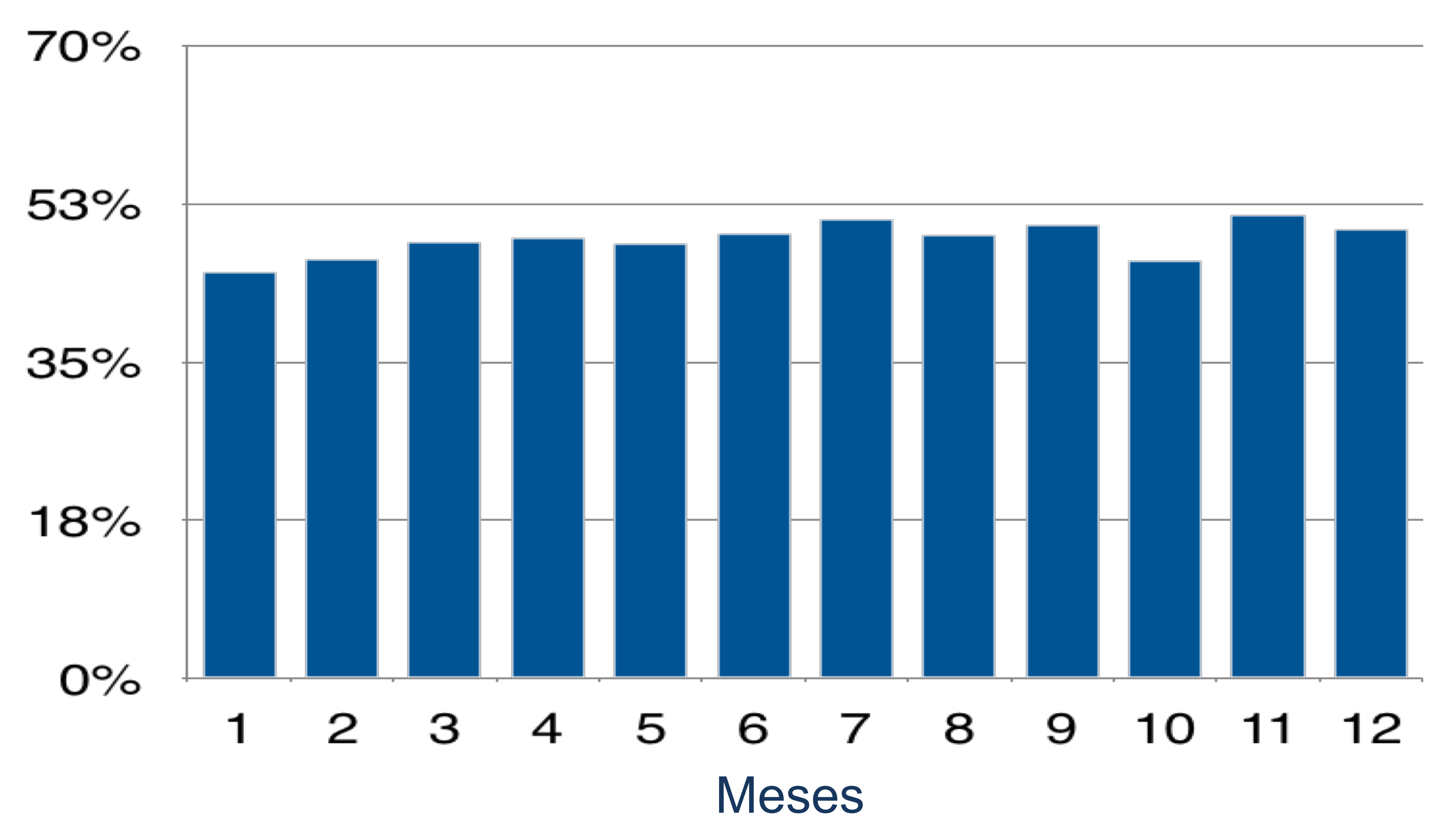

Método: Guiados pela estratégia de melhoria continua, iniciamos um trabalho piloto de engajamento por adesão da equipe médica e aumentamos a participação da equipe multiprofissional na organização do processo de desospitalização.

\section{Resultados:}

- A neurologia elevou suas taxas de $49 \%$ para $82 \%$.

- Na clínica médica houve incremento de $24 \%$

- Na cardiologia obtivemos incremento $20 \%$

Tais ações elevaram nosso índice geral para patamares de $63 \%$ em setembro de 2018.

Conclusão: Os esforços trouxeram importantes benefícios aos pacientes. Nossas próximas ações, estão focadas na expansão do engajamento às equipes de cirurgia, ortopedia, nefrologia e oncologia. 